\begin{tabular}{ccc}
\hline Mantrals & INDUSTRIAL \\
HEALTHCARE SYSTEM & MANAGEMENT \\
\hline
\end{tabular}

\title{
Organisational commitment level of subcontracted labourers working at public hospitals: Case of Sanliurfa
}

\author{
Hüseyin ERIŞS $^{1^{*}}$, Yasemin KÜÇÜKÖZKAN $^{2}$, Baran ARSLAN $^{3}$ \\ ${ }^{1}$ Vocational School of Health Services, Harran University, Sanliurfa, Turkey \\ ${ }^{2}$ Şanliurfa Public Health Provincial Directorate \\ ${ }^{3}$ Faculty of Economics and Administrative Sciences,Harran University, Sanliurfa, Turkey
}

\begin{abstract}
Keywords:

Outsourcing,

Subcontracted Labourer, Organisational

Commitment

Correspondence: erisharran@hotmail.com

The study was conducted to examine the organisational commitment of employees/subcontracted labourers, who were employed by using outsourcing method at 15 hospitals affiliated with the Public Hospitals Administration of Turkey in the province of Şanlıurfa and Harran University Research and Application Hospital to determine the correlation between demographic variables and organisational commitment. Organisational Commitment Scale with 18 items, developed by Allen and Meyer (1990), was used in the study. It was determined that the reliability rate of the Organisational Commitment Scale was 0.89 and this rate for its subscales was 0.90 for affective commitment, 0.77 forcontinuance commitment, and 0.75 for normative commitment. A statistically significant difference was found between the organisational commitment levels of employees participating in the study in terms of age, gender, marital status, educational background, and occupation. There was no statistically significant difference between the groups only in terms of working duration. A positive correlation was determined between demographic characteristics and organisational commitment.
\end{abstract}

(C)AIMI Journals

\section{Introduction}

Organisational commitment, which has been discussed since the 1950s, has become popular among organisational behaviour subjects, is based on management strategies applied by organisation and indicates the commitment of employees to organisation; following this, it is undoubtedly addressed as an important component in reaching organisational success (Brewer, 1996; Burgess \& Turner, 2000; Darrough, 2006; Gül, 2003). Lack of a common 
definition and measurement for the concept of organisational commitment in the literature leads the subject to be examined multidimensionally (Çöl, 2004; Meyer \& Herscovitch, 2001).

There are various definitions of organisational commitment in the literature. Allen and Meyer (1990) signify organisational commitment as a psychological state that connects an individual to an organisation. In other words, it is expressed as a psychological state that determines the relationship of employees with their organisation and affects their decision of either remaining a member of the organisation or leaving the organisation(Meyer \& Allen, 1990). Wahn(1998), on the other hand, defines organisational commitment as a sense of belonging in employees toward the organisation where they work. Marchiori, Alan, and Henkin(2004) indicate that organisational commitment is a concept contributing to the organisation positively and creating a value in the working environment. Erickson considers organisational commitment as contribution to the organisation by an individual and explains these contributions as the increase of organisational performance, elimination of absenteeism, and minimization of employee turnover rate (Erickson, 2007). According to some other definitions, organisational commitment is defined as an interest in organisation (Buchanan, 1974); as a psychological state determining the relationship betweenemployee and organisation (Best, 1994); or as a bonding that involves work commitment, loyalty, and faith in organisational values established by individuals with their organisation (O'Reilly, 1989).

There are also definitions about organisational commitment in the studies conducted by Turkish researchers. In their study, Durna and Eren (2006)define organisational commitment as the desire of individuals to show an effort and sustain their loyalty to the organisation for accepting the goals and values of the organisation and achieving its goals; on the other hand, Özsoy (2004) expresses organisational commitment as employees valuing the benefits of the organisation above their own benefits. To this end, the present study was conducted to examine the organisational commitment of employees/subcontracted labourers, who were employed by using outsourcing method at 15 hospitals affiliated with the Public Hospitals Administration of Turkey in the province of Şanlıurfa and Harran University Research and Application Hospital to determine the correlation between demographic variables and organisational commitment.

\section{The Literature Review}

In the study conducted by Steers(1977) on 382 hospital employees, it was determined that there was a positive correlation between organisational commitment and personality traits, work specifications and experience.Morrow and Wirth (1989)found out that there were strong correlations between performance, job safety, individuals' need for self-realization, and organisational commitment. Following this, it has been determined that the level of organisational commitment increases the work performance (Rayton, 2006; Somers \&

Birnbaum, 2000; Carson, Carson, Roe, Birkenmeier, \& Phillips, 1999) and decreases the work turnover rate (Blau \& Boal, 1987; Trimble, 2006). 


\section{Factors Affecting the Organisational Commitment}

In many studies in the literature, it is seen that there is a correlationbetween gender, age, education, working duration, and organisational commitment (Angle \& Perry, 1981; Durna \& Eren, 2006; Glisson \& Durick, 1988; Morris \& Sherman, 1981; Mottaz, 1987); whereas, there is no correlation in some studies (Nijhof,De Jong, \& Beukhof, 1998). When the studies are examined, it is observed that there is a strong correlation between organisational commitment and demographic factors. When examiningthe gender factor, it is seen that women show a higher commitment than men (Alvi \& Ahmed, 1987). In the literature, it is stated that there is a positive correlation between age, seniority, and organisational commitment (Luthans, Baack, \& Taylor, 1987; Mathieu \& Zajac, 1990). It is seen that there is areversecorrelation between education and organisational commitment and as the educational level increases, the commitment level decreases. Also, individuals who have low educational level and do not consider to receive education in the future show a higher commitment (Hrebiniak \& Alutto, 1973).

Mathieu and Zajac (1990) concluded that there was a direct positive correlation between organisational commitment and concepts of marital status, age, wage, field of activity, and talent variety. In their study, Meyer Stanley, Herscovitch, and Topolnytsky (2002) emphasised that there was a positive correlation between age and seniority and affective, continuance and normative subscales of organisational commitment.

In the study of Grusky (1966), it was reported that commitment levels were higher in high school graduates than university graduates and in women than men. The reason for women to have higher commitment levels was associated with obstacles they encountered while getting their positions. In thestudy of Al- Aameri (2000), it was concluded that married nurses had a higher commitment than widowed nurses.

In the study conducted by Steers (1977) on 382 hospital employees, it was determined that there was a positive correlation between organisational commitment and personality traits, work specifications, and experience.

\section{Organisational Commitment Model}

Many scientists define organisational commitment models in various ways. Even though every model is sufficient to explain the underlying reasons of human behaviours, it is suggested that multidimensional models can explain the organisational commitment of individuals better. There are many commitment models in the literature; Meyer and Allen (1991) developed a model in which they categorised organisational commitment in three subscales as affective, continuance, and normative (obligatory) commitment.

Affective Commitment: Affective commitment is a phenomenon that develops as a result of the coherence of individual and organisational values that allow employees to affectively commit to the organisation and feel happy due to the sense of belonging toorganisation (Wiener, 1982). Meyer and Allen (1991) express the concept of affective commitment as the ability of employees to identify themselves within the organisation and participate in the organisation. Employees accept the organisation as a part of their families and display their loyalty to it (Bobbie,2007). According to Allen and Meyer (1991), the factors 
affectingaffective commitment involvejob difficulty, role clarity, openness of management to suggestions, friendship commitment, ethics, justice, involvement, feedback, and personal importance.Employees, who have a strong affective commitment to their organisation, integrate with their organisation and have a greater desire to make more contribution (Allen \& Meyer, 1990).

Continuance Commitment: This commitment prioritizes the economic interest of employees. Employees see the maintenance of their existence in the organisation as a need by considering their investments and costs in the organisation throughout their work duration (Bergman, 2006). In this type of commitment, individuals continue to work in the organisation in order not to have a financial loss. In other words, they think that they would pay a high price if they left the organisation (Ölçüm, 2004). Employees sustain their membership to the organisation as they think that they would pay a high price if they left the organisation (Kaya \& Selçuk, 2007). Increasing investments and weak job alternatives are associated with strong tendencies of employees to continue their work in the organisation and they may develop an organisational commitment due to the need (Meyer, Paunonen, \& Gellatly, 1990). Employees continue to work in the organisation due to reasons such as the failure of finding a job, the desire not to leave their colleagues, opportunities and conditions of retirement, the desire of remaining in the same dwelling, familial conditions, and income loss (Doğar, 2013).

Normative (Obligatory) Commitment: Normative commitment is the sense of obligation for continuing to work (Meyer \& Allen, 1997). Normative commitment is also defined as employee'sworkbehaviour that is directed by emotions like duty, obligation, and loyalty toward the organisation (Wiener \& Vardi, 1980). In this type of commitment, employeesfeel indebted to the organisation (Ünler, 2006). Employeeswith normative commitment always have tendency to do the best for their organisation and displayappropriate workbehaviours (Allen \& Meyer, 1990). Thus, these employeesdisplay a higher involvement in the work (Meyer \& Allen, 1997). Normative commitment is affected by factors such asorganisational culture, age, education, and duration of service (Dordevic, 2004).

\section{Method}

This study was conducted to determine the organisational commitment levels of subcontracted labourers working at hospitals affiliated with the Public Hospitals Administration of Turkey in the province of Şanlıurfa and Harran University Research and Application Hospital.

The aim of the study isto examine the organisational commitment of employees, who were employed by using outsourcing method at 15 hospitals affiliated with the Public Hospitals Administration of Turkey in the province of Şanliurfa and Harran University Research and Application Hospital and to determine the correlation between demographic variables and organisational commitment.

In the present study, a scale consisting of two parts was used. These parts involve "Organisational Commitment Scale with 18 items" developed by Allen and Meyer (1990) 
and "Socio-Demographic Information Questions with 6 items". The scale involves totally 24 questions. Meyer and Allen's Organisational Commitment Scale used in this study has a total of18 items and is responded as 6-point Likert scale. Items in the scale are required to be responded by selecting one of the options; $1=$ Strongly Agree, $2=$ Fairly Agree, $3=$ Agree, 4= Slightly Disagree, 5= Disagree, and 6= Strongly Disagree according to their severity degree. In terms of the aim of the study, the most positive itemsget the highest score in the scale, whereas the most negative itemsget the lowest score.

Organisational Commitment Scale consists of 3 subscales as affective commitment, continuance commitment, and normative commitment. The subscale of affective commitment consists of 6 items, the subscale of continuance commitment consists of 6 items, and the subscale of normative commitment consists of 6 items.

The population of the study consisted of approximately 2000 subcontracted labourers who were employed by using outsourcing method at 15 hospitals affiliated with the Public Hospitals Administration of Turkey in the province of Şanluurfa and Harran University Research and Application Hospital. The study was conducted between 01.08.2016 and 31.12.2016. The entire population was tried to be reached without selecting a sample group. As a result of the study, $1.13(57 \%)$ subcontracted labourers filled the questionnaire and participated in the study.

The data acquired from the study were analysed by using the SPSS 22 (Statistical Programme for Social Sciences). The analyses were conducted using descriptive statistical techniques, reliability analysis, t- test, anova, and multiple regression analysis. The acquired data were tabularized in accordance with the aims of the study.

The reliability of a scale is measured by using internal consistency analysis, where Cronbach's Alpha coefficient is used. This value is between 0-1 and the acceptable value is required to be at least 0.7 . Table 1 shows the results of the reliability analysis (Cronbach's Alpha, mean, and standard deviation of the scale used in the study).

Table 1

Reliability Analysis of the Organisational Commitment Scale

\begin{tabular}{lcccc}
\hline Subscale & Number of Items & Cronbach's Alpha & Mean & Std. Deviation \\
\hline Scale & 18 & 0.89 & & 1.04 \\
Affective Commitment & 6 & 0.90 & 4.76 & 1.12 \\
Continuance Commitment & 6 & 0.77 & 4.19 & 1.03 \\
Normative Commitment & 6 & 0.75 & 4.40 & \\
\hline
\end{tabular}

When examining Table 1, the reliability rate of the Organisational Commitment Scale was determined as 0.89 , which was accepted as a high value. When the subscales of the Organisational Commitment Scale were examined, it was determined that this rate was 0.90 for the subscale of affective commitment, 0.77 for the subscale of continuance commitment, and 0.75 for the subscale of normative commitment. The reliability of the scale and the subscalesis at acceptable level for social sciences. The fact that the subscales of Organisational Commitment Scale were reliable strengthened the expectation for obtaining consistent results from the assessment in the study. 


\section{Results}

This section involves the analyses of the study.Table 2 shows the frequencies and percentages related to the distributions of subcontracted labourers participating in the study in terms of their demographic variables.

Table 2

Demographic Information of theParticipants

\begin{tabular}{|c|c|c|c|c|c|}
\hline & Frequency & Percentage & & Frequency & Percentage \\
\hline Age & & & Occupation & & \\
\hline 25 years or younger & 139 & 12.2 & Medical Secretary & 320 & 28.1 \\
\hline 26-31 years & 329 & 28.9 & Janitor & 506 & 44.5 \\
\hline 32-37 years & 305 & 26.8 & Caregiver & 42 & 3.7 \\
\hline $38-43$ years & 230 & 20,2 & Security & 210 & 18.5 \\
\hline 44 years or older & 134 & 11.8 & Other & 59 & 5.2 \\
\hline Educational Level & & & Working duration & & \\
\hline Primary School & 445 & 39.1 & $0-3$ years & 351 & 30.9 \\
\hline High School & 525 & 46.2 & $4-6$ years & 351 & 30.9 \\
\hline Associate Degree & 116 & 10.2 & $7-9$ years & 243 & 21.4 \\
\hline Bachelor's Degree & 51 & 4.5 & 10 years and above & 192 & 16.9 \\
\hline Marital Status & & & Gender & & \\
\hline Married & 859 & 75.5 & Female & 234 & 20.6 \\
\hline Single & 235 & 20.7 & Male & 903 & 79.4 \\
\hline Divorced & 43 & 3.8 & & & \\
\hline Total & 1137 & & & & \\
\hline
\end{tabular}

As it is seen in Table 2, 12.2\% of the subcontracted labourerswho participated in the study were 25 years old and younger, $28.9 \%$ were aged between $26-31$ years, $26.8 \%$ were aged between 32-37 years, 20.2\% were aged between 38-43 years, and $11.8 \%$ were 44 years old and older. Following this, $20.6 \%$ of the participants were female and $79.4 \%$ were male and $75.5 \%$ of the personnel that constituted the sample group were married, $20.7 \%$ were single, and 3.8\% were divorced. When examining in terms of education, it was found that $39.1 \%$ of the personnel were primary school graduates, $46.2 \%$ were high school graduates, $10.2 \%$ had associate degree, and $4.5 \%$ had bachelor's degree. Also, $28.1 \%$ of the participants were medical secretary, $44.5 \%$ were janitor, $3.7 \%$ were caregiver, $18.5 \%$ were security, and $4.2 \%$ were in other occupational group. In terms of the working duration, $30.9 \%$ of the personnel had been working for $0-3$ years, $30.9 \%$ for $4-6$ years, $21.4 \%$ for $7-9$ years, and $16.9 \%$ for 10 years and above. 
Table 3

Examining the Subscales of Organisational CommitmentScale in terms of the Variable of Age Group

\begin{tabular}{|c|c|c|c|c|c|c|}
\hline & Age Groups & $\mathrm{N}$ & Mean & Std. Deviation & $\mathrm{F}$ & $\mathrm{p}$ \\
\hline \multirow{6}{*}{ Affective Commitment } & 25 years or younger & 139 & 4.46 & 1.06 & \multirow{6}{*}{6.33} & \multirow{6}{*}{0.00} \\
\hline & 26-31 years & 329 & 4.65 & 1.09 & & \\
\hline & $32-37$ years & 305 & 4.84 & 0.99 & & \\
\hline & $38-43$ years & 230 & 4.95 & 1.00 & & \\
\hline & 44 years or older & 134 & 4.81 & 1.01 & & \\
\hline & Total & 1137 & 4.76 & 1.04 & & \\
\hline \multirow{6}{*}{ Continuance Commitment } & 25 years or younger & 139 & 3.95 & 1.10 & \multirow{6}{*}{3.33} & \multirow{6}{*}{0.01} \\
\hline & $26-31$ years & 329 & 4.13 & 1.16 & & \\
\hline & $32-37$ years & 305 & 4.19 & 1.08 & & \\
\hline & $38-43$ years & 230 & 4.32 & 1.13 & & \\
\hline & 44 years or older & 134 & 4.36 & 1.07 & & \\
\hline & Total & 1137 & 4.19 & 1.12 & & \\
\hline \multirow{6}{*}{ Normative Commitment } & 25 years or younger & 139 & 4.26 & 1.10 & \multirow{6}{*}{1.81} & \multirow{6}{*}{0.12} \\
\hline & 26-31 years & 329 & 4.35 & 1.06 & & \\
\hline & $32-37$ years & 305 & 4.51 & 0.97 & & \\
\hline & $38-43$ years & 230 & 4.42 & 1.02 & & \\
\hline & 44 years or older & 134 & 4.42 & 1.00 & & \\
\hline & Total & 1137 & 4.40 & 1.03 & & \\
\hline
\end{tabular}

Table 3 shows the examination of the subscales of Organisational Commitment Scale in terms of the variable of age groups. ANOVA test was used for investigating whether there was a statistically significant difference between these subscales in terms of the variable of age groups. As a result of the statistical test, a statistically significant difference was determined between the subscales of affective commitment and continuance commitment in terms of the variable of age groups. Tukey test was applied for determining the reason of the difference and it was observed to be caused by the difference between the means of the age groups of 25 years or younger and 32-37 years, between the means of the age groups of 25 years or younger and 38-43 years, between the means of the age groups of 25 years or younger and 44 years or older, and between the means of the age groups of 26-31 years and 38-43 years in the subscale of affective commitment. Also, it was observed to be caused by the difference between the means of the age groups of 25 years or younger and 38-43 years and between the means of the age groups of 25 years or younger and 44 years or older in the subscale of continuance commitment. Table 4 shows the examination of the subscales of Organisational Commitment Scale in terms of the variable of gender.

Table 4

Examining the Subscales of Organisational Commitment Scale in terms of the Variable of Gender

\begin{tabular}{|c|c|c|c|c|c|c|}
\hline & Gender & $\mathrm{N}$ & Mean & Std. Deviation & $\mathrm{t}$ & $\mathrm{P}$ \\
\hline \multirow{2}{*}{ Affective Commitment } & Female & 234 & 4.40 & 1.01 & \multirow{2}{*}{-5.94} & \multirow{2}{*}{0.00} \\
\hline & Male & 903 & 4.85 & 1.03 & & \\
\hline \multirow{2}{*}{ Continuance Commitment } & Female & 234 & 3.99 & 1.03 & \multirow{2}{*}{-2.97} & \multirow{2}{*}{0.00} \\
\hline & Male & 903 & 4.24 & 1.14 & & \\
\hline \multirow{2}{*}{ Normative Commitment } & Female & 234 & 4.09 & 0.93 & \multirow{2}{*}{-5.21} & \multirow{2}{*}{0.00} \\
\hline & Male & 903 & 4.48 & 1.04 & & \\
\hline
\end{tabular}


Student-t test was used to investigate whether there was a statistically significant difference between these subscales in terms of the variable of gender. As a result of the statistical test, a statistically significant difference was determined in all three subscales in terms of the variable of gender. When examining the means, it was observed that men had higher mean scores in all three subscales. Table 5 presents the examination of the subscales of Organisational Commitment Scale in terms of the variable of marital status.

Table 5

Examining the Subscales of Organisational Commitment Scale in terms of the Variable of Marital Status

\begin{tabular}{|c|c|c|c|c|c|c|}
\hline & Marital Status & $\mathrm{N}$ & Mean & Std. Deviation & $\mathrm{t}$ & $\mathrm{P}$ \\
\hline \multirow{4}{*}{ Affective Commitment } & Married & 859 & 4.81 & 1.04 & \multirow{4}{*}{5.63} & \multirow{4}{*}{0.00} \\
\hline & Single & 235 & 4.56 & 1.06 & & \\
\hline & Divorced & 43 & 4.71 & 0.92 & & \\
\hline & Total & 1137 & 4.76 & 1.04 & & \\
\hline \multirow{4}{*}{$\begin{array}{l}\text { Continuance } \\
\text { Commitment }\end{array}$} & Married & 859 & 4.25 & 1.11 & \multirow{4}{*}{6.64} & \multirow{4}{*}{0.00} \\
\hline & Single & 235 & 3.95 & 1.15 & & \\
\hline & Divorced & 43 & 4.28 & 0.94 & & \\
\hline & Total & 1137 & 4.19 & 1.12 & & \\
\hline \multirow{4}{*}{ Normative Commitment } & Married & 859 & 4.46 & 1.02 & \multirow{4}{*}{6.54} & \multirow{4}{*}{0.00} \\
\hline & Single & 235 & 4.19 & 1.09 & & \\
\hline & Divorced & 43 & 4.45 & 0.76 & & \\
\hline & Total & 1137 & 4.40 & 1.03 & & \\
\hline
\end{tabular}

ANOVA test was used to investigate whether there was a statistically significant difference between these subscales in terms of the variable of marital status. As a result of the statistical test, a statistically significant difference was determined in all three subscales in terms of the variable of marital status. Tukey test was applied to determine the reason of the difference and it was observed to be caused by the difference between the means of married and single groups in all three subscales. Table 6 exhibits the examination of the subscales of Organisational Commitment Scale in terms of the variable of education.

Table 6

Examining the Subscales of Organisational Commitment Scale in terms of the Variable of Educational Level

\begin{tabular}{|c|c|c|c|c|c|c|}
\hline & Educational Level & $\mathrm{N}$ & Mean & Std. Deviation & $\mathrm{t}$ & $\mathrm{P}$ \\
\hline \multirow{5}{*}{ Affective Commitment } & Primary School & 445 & 4.87 & 0.99 & \multirow{5}{*}{8.99} & \multirow{5}{*}{0.00} \\
\hline & High School & 525 & 4.77 & 1.02 & & \\
\hline & Associate Degree & 116 & 4.56 & 1.11 & & \\
\hline & Bachelor's Degree & 51 & 4.15 & 1.26 & & \\
\hline & Total & 1137 & 4.76 & 1.04 & & \\
\hline \multirow{5}{*}{ Continuance Commitment } & Primary School & 445 & 4.47 & 1.11 & \multirow{5}{*}{16.86} & \multirow{5}{*}{0.00} \\
\hline & High School & 525 & 4.05 & 1.09 & & \\
\hline & Associate Degree & 116 & 3.85 & 1.11 & & \\
\hline & Bachelor's Degree & 51 & 3.93 & 1.09 & & \\
\hline & Total & 1137 & 4.19 & 1.12 & & \\
\hline \multirow{5}{*}{ Normative Commitment } & Primary School & 445 & 4.57 & 0.95 & \multirow{5}{*}{8.43} & \multirow{5}{*}{0.00} \\
\hline & High School & 525 & 4.34 & 1.02 & & \\
\hline & Associate Degree & 116 & 4.23 & 1.14 & & \\
\hline & Bachelor's Degree & 51 & 3.99 & 1.22 & & \\
\hline & Total & 1137 & 4.40 & 1.03 & & \\
\hline
\end{tabular}


ANOVA test was used to investigate whether there was a statistically significant difference between these subscales in terms of the variable of educational level. As a result of the statistical test, a statistically significant difference was determined in all three subscales in terms of the variable of educational level. Tukey test was applied for determining the reason of the difference and it was observed to be caused by:

i. the difference between the means of the groups of Primary School and Associate Degree, between the means of the groups of Primary School and Bachelor's degree, and between the means of the groups of High School and Bachelor's degree in the subscale of affective commitment,

ii. the difference between the means of the groups ofPrimary School and High School, between the means of the groups of Primary School and Associate Degree, and between the means of the groups of Primary School and Bachelor's degree in the subscale of continuance commitment,

iii. the difference between the means of the groups of Primary School and High School, between the means of the groups of Primary School and Associate Degree, and between the means of the groups of Primary School and Bachelor's degree in the subscale of normative commitment.

Table 7 displays the examination of the subscales of Organisational Commitment Scale in terms of the variable of occupation.

Table 7

Examining the Subscales of Organisational CommitmentScale in terms of the Variable of Occupation

\begin{tabular}{|c|c|c|c|c|c|c|}
\hline & Occupation & $\mathrm{N}$ & Mean & Std. Deviation & $\mathrm{t}$ & $\mathrm{P}$ \\
\hline \multirow{6}{*}{ Affective Commitment } & Medical Secretary & 320 & 4.66 & 1.10 & \multirow{6}{*}{8.06} & \multirow{6}{*}{0.00} \\
\hline & Junitor & 506 & 4.89 & 1.02 & & \\
\hline & Caregiver & 42 & 4.20 & 0.77 & & \\
\hline & Security & 210 & 4.68 & 1.03 & & \\
\hline & Other & 59 & 4.35 & 0.99 & & \\
\hline & Total & 1137 & 4.55 & 1.05 & & \\
\hline \multirow{6}{*}{ Continuance Commitment } & Medical Secretary & 320 & 4.02 & 1.06 & \multirow{6}{*}{21.51} & \multirow{6}{*}{0.00} \\
\hline & Janitor & 506 & 4.47 & 1.15 & & \\
\hline & Caregiver & 42 & 4.01 & 0.65 & & \\
\hline & Security & 210 & 3.83 & 1.06 & & \\
\hline & Other & 59 & 3.99 & 1.01 & & \\
\hline & Total & 1137 & 4.06 & 1.12 & & \\
\hline \multirow{6}{*}{ Normative Commitment } & Medical Secretary & 320 & 4.29 & 1.10 & \multirow{6}{*}{9.38} & \multirow{6}{*}{0.00} \\
\hline & Janitor & 506 & 4.56 & 1.00 & & \\
\hline & Caregiver & 42 & 3.99 & 0.55 & & \\
\hline & Security & 210 & 4.25 & 0.99 & & \\
\hline & Other & 59 & 4.07 & 0.85 & & \\
\hline & Total & 1137 & 4.23 & 1.02 & & \\
\hline
\end{tabular}

ANOVA test was run to investigate whether there was a statistically significant difference between these subscales in terms of the variable of occupation. As a result of the statistical test, a statistically significant difference was determined in all three subscales in terms of the 
variable of occupation. Tukey test was applied for determining the reason of the difference and it was observed to be caused by:

i. the difference between the means of the groups of Medical Secretary and Janitor, between the means of the groups of Medical Secretary and Caregiver, and between the means of the groups of Janitor and Caregiver in the subscale of affective commitment,

ii. the difference between the means of the groups of Medical Secretary and Janitor, between the means of the groups of Caregiver and Janitor, and between the means of the groups of Security and Janitor in the subscale of continuance commitment,

iii. the difference between the means of the groups of Medical Secretary and Janitor, between the means of the groups of Caregiver and Janitor, and between the means of the groups of Security and Janitor in the subscale of normative commitment.

Table 8 shows the examination of the subscales of Organisational Commitment Scale in terms of the variable of working duration.

Table 8

Examining the Subscales of Organisational Commitment Scale in terms of the Variable of Working Duration

\begin{tabular}{|c|c|c|c|c|c|c|}
\hline & Occupation & $\mathrm{N}$ & Mean & Std. Deviation & $\mathrm{t}$ & $\mathrm{P}$ \\
\hline \multirow{5}{*}{ Affective Commitment } & $0-3$ years & 351 & 4.76 & 1.01 & \multirow{5}{*}{1.48} & \multirow{5}{*}{0.2} \\
\hline & 4-6 years & 351 & 4.74 & 1.00 & & \\
\hline & $7-9$ years & 243 & 4.68 & 1.14 & & \\
\hline & 10 years and above & 192 & 4.89 & 1.03 & & \\
\hline & Total & 1137 & 4.76 & 1.04 & & \\
\hline \multirow{5}{*}{ Continuance Commitment } & $0-3$ years & 351 & 4.16 & 1.11 & \multirow{5}{*}{0.92} & \multirow{5}{*}{0.42} \\
\hline & 4-6 years & 351 & 4.14 & 1.14 & & \\
\hline & $7-9$ years & 243 & 4.29 & 1.10 & & \\
\hline & 10 years and above & 192 & 4.19 & 1.14 & & \\
\hline & Total & 1137 & 4.19 & 1.12 & & \\
\hline \multirow{5}{*}{ Normative Commitment } & $0-3$ years & 351 & 4.47 & 1.02 & \multirow{5}{*}{1.73} & \multirow{5}{*}{0.15} \\
\hline & 4-6 years & 351 & 4.30 & 1.02 & & \\
\hline & $7-9$ years & 243 & 4.43 & 1.03 & & \\
\hline & 10 years and above & 192 & 4.43 & 1.04 & & \\
\hline & Total & 1137 & 4.40 & 1.03 & & \\
\hline
\end{tabular}

ANOVA test was employed to investigate whether there was a statistically significant difference between these subscales in terms of the variable of working duration. As a result of the statistical test, no statistically significant difference was determined in the subscales in terms of the variable of working duration. Table 9 represents the correlation coefficients between the subscales of organisational commitment. When examining the correlation coefficients, it was observed that all three coefficients were positive and statistically significant. 
Table 9

Correlation Coefficients Between the Subscales of Organisational Commitment Scale

\begin{tabular}{llcc}
\hline & Affective & Continuance & Normative \\
\hline 1. Affective Commitment & 1 & & \\
2. Continuance Commitment & $0.49^{* *}$ & 1 & \\
3. Normative Commitment & $0.64^{* *}$ & $0.59^{* *}$ & 1
\end{tabular}

\section{Discussion}

This study was conducted to determine whether the organisational commitment of subcontracted labourers working at public hospitals differed within the context of demographic factors. The demographic factors that were questioned within the scope of the study and had a correlation with organisational commitmentwere determined as gender, age, marital status, education, occupation, and working duration. In numerous studies in the literature, a correlation was determined between gender, age, education, working duration, and organisational commitment (Angle \& Perry, 1981; Durna \& Eren, 2005; Glisson \& Durick, 1988; Morris \& Sherman, 1981; Mottaz, 1987), whereas, no correlation was determined in some studies (Nijhof et al., 1998). When examining the studies, it was observed that there was a strong correlation between organisational commitment and demographic factors. In the study, the subscales of Organisational Commitment Scale were examined in terms of the variable of age groups and as a result of the statistical test, a statistically significant difference was determined between the subscales of affective commitment and continuance commitment in terms of the variable of age groups. The results showed a parallelism with some studies in theliterature (Luthans et al., 1987; Mathieu \& Zajac, 1990; Meyer et al., 2002). In the study, the subscales of Organisational Commitment Scale were examined in terms of the variable of gender and as a result of the statistical test, a statistically significant difference was determined in all three subscales in terms of the variable of gender. When examining the means, it was observed that men had higher means in all three subscales. Similar results are obtained in similar studies in literature (Alvi \& Ahmed, 1987; Grusky, 1996; Mathieu\& Zajac, 1990; Grusky, 1966).

When the subscales of Organisational Commitment Scale were examined in terms of the variable of marital status in the study, a statistically significant difference was determined in all three subscales in terms of the variable of marital status. Tukey test was applied for determining the reason of the difference and this was associated with the difference between the means of married and single groups in all three subscales. Married individuals had higher means compared to single individuals. In the study of Al-Aameri(2000)it was determined that married personnel had a higher commitment than widowed nurses. In the study, the subscales of Organisational Commitment Scale were tested in terms of the variable of educational background and a statistically significant difference was determined in all three subscales in terms of the variable of educational background. It was determined that the difference was generally caused by primary school graduates and they had higher means than other graduate groups, which was mainly associated with the fact that as the educational level increased, the opportunity of finding a better and more convenient job increased. The similar results were 
obtained in the studies in the literature (Hrebiniak \& Alutto, 1973; Mathieu\& Zajac, 1990; Grusky, 1966).

When the subscales of Organisational Commitment Scale were examined in terms of the variable of occupation, it was found that there was a statistically significant difference in all three subscales in terms of the variable of occupation. A statistically significant difference was determined between the occupations of medical secretary, janitor, and caregiver and in terms of the means, janitors had higher means. In the study, the subscales of Organisational Commitment Scale were investigated in terms of the variable of working duration and no statistically significant difference was determined. When the means were examined, it was observed that the means of the group of 10 years and above in the subscale of affective commitment, the group of 7-9 years in the subscale of continuance commitment, and the group of 0-3 years in the subscale of normative commitment were higher than other the groups.Finally, the correlation coefficients between the subscales of organisational commitment scale were examined and the results showed that all three coefficients were positive and statistically significant.

\section{Conclusion}

In this study, it was aimed to examine the organisational commitment of employees, who were employed by using outsourcing method at 15 hospitals affiliated with the Public Hospitals Administration of Turkey in the province of Şanliurfa and Harran University Research and Application Hospital, and to determine the correlation between demographic variables and organisational commitment. For this purpose, the Organisational Commitment Scale with 18 items that was developed by Allen and Meyer (1990) and a series of sociodemographic questions were used. The entire population was tried to be reached without selecting a sample group. As a result of the study, $1.13(57 \%)$ out of approximately 2000 subcontracted labourers filled the questionnaire and participated in the study.

The current study described the concept of organisational commitment and examined the theoretical bases of the concept.Organisational commitment theories examined in literature were investigated and the subscales of the concept were defined. In the study, a literature review was conducted and related studies conducted both inland and abroad were evaluated. The study is considered important since it addressed the concept of organisational commitment and presented it with a broad conceptual examination and a field research was conducted on subcontracted labourers who work at hospitals offering healthcare services. Additionally, the study cannot be generalized to Turkey. It is thought that the study will be useful for future studies on this subject and making comparison with previous studies.

A statistically significant difference was determined between the organisational commitment levels of healthcare professionals, who participated in the study, in terms of age, gender, marital status, education, and occupation. No statistically significant difference was determined between the groups only in terms of working duration. There was a positive correlation between demographic characteristics and organisational commitment.

In the light of these data, somerecommendations could be made: Employees whose needs are met and who have job satisfaction can be more productive in workplaces. Thus, modern managers working at health organisations are expected to increase the organisational 
commitment of subcontracted labourers. Following this, a number of opportunities should be offered to increase the organisational commitment ofsubcontracted labourers in the personnel group, who are young, single, female, and have a high educational level in order to increase their organisational commitment levels and use their energy better.

\section{References}

Al-Aameri, A., S. (2000). Job satisfaction and organizational commitment for nurses. Saudi Medical Journal, 21(6), 531535.

Allen, N. J., \& Meyer, J. P. (1990). The measurement and antecedents of affective, continuance and normative commitment to the organization. Journal of Occupational \& Organizational Psychology, 63, 1-18.

Alvi, S. A., \& Ahmed, S. W. (1987). Assesing organizational commitment in a developing country: Pakistan, a case study. Human Relations, 40(5), 267-280.

Angle, H., L.. Perry, J., L. (1981). An emprical assessment of organizational commitment and organizational effectiveness. Administrative Science Quarterly, 21, 1-14.

Bergman, M. E. (2006). The relationship between affective and normative commitment: Review and research agenda. Journal of Organizational Behavior, 27, 645-663.

Best, P. W. (1994). Locus of control, personal commitment and commitment to the organization (Unpublished M.Com thesis).University Of South Africa, Pretoria.

Blau, G., \& Boal, K. (1987). Conceptualizing how job involvement and organizational commitment affect turnover and absenteeism. Academy of Management Review, 12(2), 288-300.

Bobbie, M. T. Jr. (2007). An analysis of the relationships among job satisfaction, organizational trust, and organizational commitment in an acute care hospital (Doctoral dissertation). San Francisco, California.

Brewer, A., M. (1996). Developing commitment between managers and employees. Journal of Managerial Psychology, $11(4), 24-34$.

Buchanan, B.(1974). Building organizational commitment: The socialization of managers in work organizations. Administrative Science Quarterly, 19(4), 533-546.

Burgess, R., \& Turner, S. (2000). Seven Key features for creating and sustaining commitment. International Journal of Project Management, 18, 225-233.

Carson, K., Carson, R., Roe, C., Birkenmeier, B., \& Phillips, J. (1999). Four commitment profiles and their relationships with empowerment, service recovery, and work attitudes. Public Personnel Management, 28, 1-13.

Çöl, G., (2004). Örgütsel bağl1lık kavramı ve benzer kavramlarla ilişkisi. İ̧s, Güç Endüstri İlişkileri Ve İnsan Kaynakları Dergisi, 6(2), 4-11.

Darrough, O. G. (2006). An Examination of the relationship between organizational trust and organizational commitment in the workforce (Unpublished doctoral dissertation). Nova Southeastern University.

Doğar, N. (2013). Kişilik,örgütsel bağglllk ve iş tatmini arasındaki ilişkilerin incelenmesi : istanbul'da faaliyet gösteren iki ticarî bankada bir araştırma (Doctoral dissertation). Çukurova Üniversitesi Sosyal Bilimler Enstitüsü, Adana.

Dordevic, B. (2004). Employee commitment in times of radical organizational changes. Facta Universitatis, Series, Economics \& Organization, 2(2), 111-117.

Durna, U., \& Eren, V. (2005). Üç Bağl1lık Unsuru Ekseninde Örgütsel Bağl1lık. Doğuş Üniversitesi Dergisi, 6(2), $210-219$.

Erıckson, R. A. (2007). Here today but what about tomorrow? Reducing the attrition of downsizing survivors by increasing their organizational commitment (Doctoral dissertation). Northwestern University.

Glisson, C., \& Durick, M. (1988). Predictors of job satisfaction and organizational commitment in human service organizations. Administrative Quarterly, 33(1), 61-81.

Grusky, O. (1966). Career mobility and organzational commitment. Administrative Science Quarterly, 10(4), 488-503.

Gül, H. (2003). Davranışsal bağlılık yaklaşımı ve değerlendirmesi. Celal Bayar Üniversitesi Yönetim ve Ekonomi Dergisi, 10(1), 73-83.

Hrebiniak, L. G., \& Alutto, J. A. (1973). Personal and role-related factors in the development of organizational commitment. Administrative Science Quarterly, 17, 555-572.

Kaya, N., \& Selçuk, S. (2007). Bireysel başarı güdüsü organizasyonel bağlılı̆̆1 nasıl etkiler? Doğuş Üniversitesi Dergisi, $8(2), 175-190$ 
Luthans, F., Baack, D.,\& Taylor, L. (1987). Organizational commitment: Analysis of antecedents. Human Relations, 40(4), 219-236.

Marchiori, D. M., Alan, B., \& Henkin, C. (2004). Organizational commitment of health profession faculty: Dimensions, corelates and conditions. Medical Teacher, 26(4), 353-358.

Mathieu, J. E., \& Zajac, D. M., (1990). A review and meta- analysis of the antecedents, correlates, and consequences of organizational commitment. Psychological Bulletin, 108(2), 171-194.

Meyer, J. P., \& Allen, N. J. (1997). Commitment in the workplace: Theory, research, and application. Thousand Oaks, CA: Sage Publications.

Meyer, J. P., Paunonen, S. V., \& Gellatly, I. R. (1990). Affective and continuance commitment to the organization: Evaluation of measures and analysis of concurrent and timelagged relations. Journal of Applied Psychology, 75(6), 710720 .

Meyer, J. P., \& Allen, N. J. (1991). A three- component conceptualization of organizational commitment. Human Resources Management Review, 1, 61-89.

Meyer, J. P., \& Herscovitch, L. (2001). Commitment in the workplace: Toward a general model. Human Resource Management Review, 11, 299-326.

Meyer, J. P., Stanley, D. J., Herscovitch, L., \& Topolnytsky, L. (2002). Affective, continuance, and normative commitment to the organization: A meta-analysis of antecedents, correlates, and consequences. Journal of Vocational Behavior, 61, $20-52$.

Morris, J. H., \& Sherman, J. D. (1981). Generalizability of an organizational commitment model. Academy of Management Journal., 24, 512-526.

Morrow, P. C., \& Wirth, R. E. (1989). Work commitment among salaried professionals. Journal of Vocational Behavior, 34, $40-56$.

Mottaz, C. J. (1987). An analysis of the relationship between work satisfaction and organizational commitment. The Sociological Quarterly, 28(4), 541-558.

Nijhof, W. J., De Jong, M. J., \& Beukhof, G. (1998). Employee Commitment in changing organizations: An exploration. Journal of European Industrial Training, 22(6), 243-248.

Ölçüm, Ç. M. (2004). Örgüt kültürü ve örgütsel bağglllık. Ankara: Nobel Yayın Dağıtım.

Oliver, N. (1990). Work rewars, work values and organizational commitment in employee-owned firm: Evidence from the U.K. Human Relations, 43(6), 513-526.

O'reilly, C. (1989). Corporations, culture, and commitment: motivation and social control in organizations. California Management Review, 31(4), 9-25.

Özsoy, S. A. (2004). Bir yüksekokul çalışanlarının kuruma bağlılık durumlarının incelenmesi. İş, Güç -Endüstri İlişkileri Ve Insan Kaynaklarl Dergisi, 6(2), 13-19.

Rayton, B. A. (2006). Examining the interconnection of job satisfaction and organizational commitment: An application of the bivariate probit model. TheInternational Journal Of Human Resource Management, 17(1), 139-154.

Somers, M., \& D. Birnbaum (2000). Exploring the relationship between commitment profiles and work attitudes, employee withdrawal, and job performance. Public Personnel Management, 29(3), 353-365.

Steers, R. M. (1977). Antecedents and outcomes of organizational commitment. Administrative Science Quarterly, 22(3), $46-56$.

Trimble, D. E. (2006). Organizational commitment, job satisfaction, and turnover intention of missionaries. Journal of Psychology \& Theology, 34, 349-360.

Ünler, E. (2006). Örgütte bağlılığın işin nitelikleri ve davranış düzeltme uygulamasıyla ilişkisi. Yönetim Bilimleri Dergisi, $4(1), 95-115$.

Wahn, J. C. (1998). Sex differences in the continuance component of organizational commitment. Group \& Organization Management, 23(3), 256-266.

Wiener, Y. (1982). Commitment and organizations: A normative view. Academy Of Management Review, 7(3), 418-428.

Wiener, Y., Vardi, Y. (1980). Relationships between job, organization and work outcomes: an integrative approach. Organizational Behavior \& Human Performance, 21 ,81-96.

Moneke, N. I, \& Umeh, O. J. (2014). How organizational commitment of critical care nurses influence their overall job satisfaction. Journal of Nursing Education \& Practice, 4(1), 148-161. 